\title{
Morphologic and Morphometric Evaluation of the Wormian Bones
}

\author{
Evaluación Morfológica y Morfométrica de los Huesos Wormianos
}

\author{
Nazire Kiliç Safak; Rümeysa Gamze Taskin \& Ahmet Hilmi Yücel
}

\begin{abstract}
KILIÇ SAFAK, N.; TASKIN, R. G. \& YÜCEL, A. H. Morphologic and morphometric evaluation of the wormian bones. Int. J. Morphol., 38(1):69-73, 2020.

SUMMARY: Wormian (sutural) bones are accessory small bones located on the skull. These bones consist of extra ossification centers around cranial sutures. This study was carried out in 28 dry human skulls with unknown age and sex in the Department of Anatomy, Cukurova University. The aim of the study was to investigate incidence and to determine morphologic and morphometric characteristics of wormian (sutural) bones. Total incidence of wormian bone presence was $42.86 \%(\mathrm{n}=12)$ and most of them were located on lambdoid suture $(57.14 \%)$. Wormian bones were seen at lambdoid suture at a rate of $62.5 \%$, occipito-mastoid suture $9.37 \%$, asterion $18.76 \%$, lambda $9.37 \%$, and were not seen on pterion, bregma, parietotemporal, sagittal and coronal sutures. Wormian bones were seen on left side at a rate of $65.62 \%$ and $34.38 \%$ on right side of skull. According to our study, wormian bone shapes were seen as quadrangular $(56.26 \%)$, triangular $(15.62 \%)$ and irregular $(28.12 \%)$. The mean values of wormian bones were as follows; vertical diameter: $12.29 \pm 4.48 \mathrm{~mm}$ and horizontal diameter: $10.93 \pm 4.39 \mathrm{~mm}$. For cephalic index, the result of our study shows that most of our skulls with or without wormian bones belong to dolichocephalic group. Knowledge of variations and characteristics of skull is important for forensic medicine, anatomy, radiology and neurosurgery fields and for literature data or clinical practices.
\end{abstract}

KEY WORDS: Wormian bone; Ossa suturali; Morphology.

\section{INTRODUCTION}

The human skull consists of 22 bones that fuse together after birth which are divided into neurocranium and visserocranium bones. The skull bones are connected with cranial sutures (Reveron, 2017; Yücel, 2018). Wormian bones or sutural bones are accessory small bones which occur accidentally or intercalated between or near cranial sutures isolated from normal ossification center of skull (Patel et al., 2015; Sreekanth \& Samala, 2016). Wormian bones were described by Danish anatomist Olaus Wormian in 1643 and Ossa wormiana was used as a term by Thomas Bartholin for these bones firstly (Albay et al., 2013; Sreekanth \& Samala). They also named these bones as ossicles, intersutural bones, intercalary bones or supernumerary bones (Showri \& Suma, 2016). However, the formation mechanism of wormian bones have not been clarified adequately yet (Gümüs, burun et al., 1997). The point of view of some authors is that wormian bones are derived from external factors such as dural strain near sutures and from intrinsic factors such as genetics (Sanchez-Lara et al., 2007; Bellary et al., 2013). The aim of the present study was to investigate incidence and to determine morphologic and morphometric characteristics of wormian (sutural) bones.

\section{MATERIAL AND METHOD}

This study was conducted with 28 dry human skulls with unknown age and sex in the Department of Anatomy, Faculty of Medicine, Cukurova University, Adana. The deformed skulls were excluded from this study. After the skulls were analyzed for presence of wormian bones, the location, number, side and shape of wormian bones were determined. Additionally, vertical-horizontal diameters of wormian bones and width-length of skulls were measured by using digital caliper nearest $0.1 \mathrm{~mm}$. The cranial index were calculated and wormian bone incidences were analyzed in different types of skulls.

The cephalic index calculation formula were as follows:

Cephalic index $(\mathrm{CI})=$ Cranial breadth (EuryonEuryon)*100/ Cranial length (Opisthocranion-Glabella)

The types of the cranium were divided into 4 groups by using the classification of Williams et al. (Table I) (Anjum et al., 2016). 
Table I. Cephalic index classification.

\begin{tabular}{lllll}
\hline Shape & Dolichocephalic & Mesocephalic & Brachycephalic & Hyperbrachycephal ic \\
\hline Cephalic index & CI $<74.9$ & $75<$ CI $<79.9$ & $80<$ CI $<84.9$ & $85<$ CI $<89.9$ \\
\hline
\end{tabular}

The SPSS 20.0 programme and the Descriptive Statistical Methods (mean, standard deviation and \%) were used for data analysis.

\section{RESULTS}

In this study, wormian bones were observed in 12 $(42.86 \%)$ skulls out of 28 skulls. More than five wormian bones were found in only one skull. The total number of the observed wormian bones were 32 and the greatest number of wormian bones were seen at lambdoid suture $(n=20,57.14$ $\%)$.Wormian bones were observed at lambdoid suture 62.5 $\%$, occipito-mastoid suture $9.37 \%$, asterion $18.76 \%$, lambda $9.37 \%$; however, they were not seen at pterion, bregma, parietotemporal, sagittal and coronal sutures (Fig. 1).
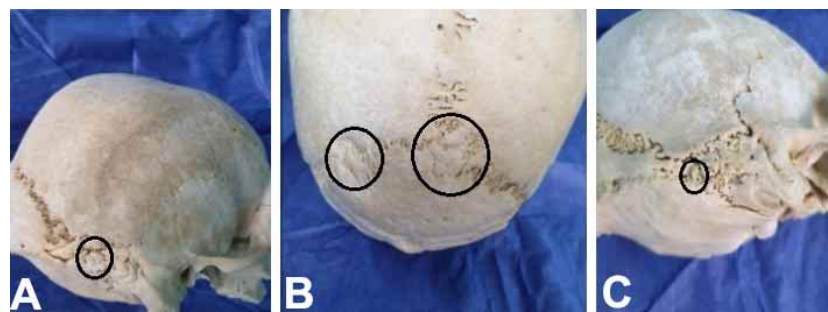

Fig. 1. Wormian bones: A) at asterion B) at Lambda and lambdoid suture $\mathrm{C}$ ) at occipitomastoid suture.

Moreover, wormian bones were seen on left side at a rate of $65.62 \%$, and at a rate of $34.38 \%$ on right side of the skulls (Table II).

When we focused on the shape of the wormian bones; $18(56.26 \%)$ were quadrangular, 5 (15.62\%) were triangular, $9(28.12 \%)$ were irregular. Additionally, the mean cranial breadth and cranial length were found as $128.06 \pm 11.92 \mathrm{~mm}$ and $166.12 \pm 5.47 \mathrm{~mm}$ respectively. When we analyzed the skulls in terms of cephalic index values, $39.28 \%$ were dolicocephalic, $28.57 \%$ mesocephalic, 10.71 $\%$ brachycephalic and $21.42 \%$ were hyperbrachycephalic skulls in our study. The most common types of skulls in the wormian bone presence group was dolichocephalic as well as in the group that did not have wormian bone. The distribution of wormian bones according to cranial index and location were as follows (Table III).

The mean values of wormian bones were as follows; vertical diameter: $12.29 \pm 4.48 \mathrm{~mm}$ and horizontal diameter: $10.93 \pm 4.39 \mathrm{~mm}$. The wormian bones were seen at lambdoid suture in 7 skulls as 20 (6 right, 14 left), at occipitomastoid suture in 3 skulls as 3 ( 1 right, 2 left), at lambda in 2 skulls as 3 (1 right, 2 left), at asterion in 3 skulls as 6 (3 right, 3 left). The mean values of right vertical dimeter were $12.67 \pm 3.62 \mathrm{~mm}$ and horizontal diameter were $10.95 \pm 3.3$ whereas the mean values of left vertical diameter were $12.86 \pm 4.37 \mathrm{~mm}$ and horizontal diameter were $11.66 \pm 5.60$ $\mathrm{mm}$ on lambdoid suture. The vertical diameter was measured as $7.7 \mathrm{~mm}$ and horizontal diameter as $7.9 \mathrm{~mm}$ in one wormian bone on right, while the mean vertical diameter and horizontal diameter on left were found as $15.77 \mathrm{~mm}$ and $9.78 \mathrm{~mm}$ for occipitomastoid suture. The mean vertical diameter was found as $14.74 \mathrm{~mm}$ and horizontal diameter was found as $10.96 \mathrm{~mm}$ for right side and the mean vertical diameter was found as $9.34 \mathrm{~mm}$ and horizontal diameter was found as $8.79 \mathrm{~mm}$ for left side on asterion. Finally, the mean values of vertical and horizontal diameter for right were measured as $10.26 \mathrm{~mm}$ and 12.47 $\mathrm{mm}$, respectively; and the mean values of vertical and horizontal diameter for left were measured as $7.83 \mathrm{~mm}$ and $10.79 \mathrm{~mm}$ at lambda.

Table II. Location of the Wormian bones $(n=32)$

\begin{tabular}{llll}
\hline $\begin{array}{l}\text { Location of the wormian } \\
\text { bones }(\mathrm{n}=32)\end{array}$ & $\begin{array}{l}\text { Right } \\
(\mathrm{n}=11,34.38 \%)\end{array}$ & $\begin{array}{l}\text { Left } \\
\mathrm{n}=21,65.62 \%)\end{array}$ & $\begin{array}{l}\text { Total } \\
(\%)\end{array}$ \\
\hline $\begin{array}{l}\text { Lambdoid suture } \\
\text { Parietotemporal suture }\end{array}$ & 14 & 6 & $20(62.5 \%)$ \\
Occipitomastoid suture & 0 & 0 & $0(0 \%)$ \\
Asterion & 2 & 1 & $3(9.37 \%)$ \\
Pterion & 3 & 3 & $6(18.76 \%)$ \\
Bregma & 0 & 0 & $0(0 \%)$ \\
Lambda & 0 & $0(0 \%)$ \\
Coronal suture & 3 & $3(9.37 \%)$ \\
S agittal suture & 0 & $0(0 \%)$ \\
\hline
\end{tabular}


Table III. Distribution of wormian bones $(n=32)$ according to location and cranial index values.

\begin{tabular}{llllll}
\hline & & $\begin{array}{l}\text { Lambdoid } \\
\text { suture }\end{array}$ & $\begin{array}{l}\text { Occipitomastoid } \\
\text { suture }\end{array}$ & Asterion & Lambda \\
\hline Dolichocephalic & $\%$ & 18.75 & 3.12 & 6.25 & 3.12 \\
Mesocephalic & $\%$ & 9.37 & 3.12 & 3.12 & 0 \\
Brachycephalic & $\%$ & 18.75 & 0 & 0 & 0 \\
Hyperbrachycephalic & $\%$ & 15.62 & 0 & 12.5 & 6.25 \\
\hline
\end{tabular}

\section{DISCUSSION}

Wormian bones (ossa suturalia), which were described by Danish anatomist Olaus Wormius firstly, are accessory, small, different-shaped bones located on cranial sutures (Cremin et al., 1982). Wormian bones are derived from unusual ossification centers in the cranium added onto the normal structure of the skull bones (Bellary et $a l$.). Artificial cranial deformation, adaptation to cranial enlargement, genetic factors and metabolic disorders were given as the reasons of wormian bones appearance (Patil \& Sheelavant, 2012). As mentioned in the literature, especially multiple wormian bones play an indicator role for central nervous system or skeletal pathology and can be used as a landmark for clinicians (Himabindu \& Rao, 2015).

According to a study which focused on morphogenesis of wormian bones, large wormian bones were higher in craniosynostosis. This study reinforced the consideration that mechanical forces affect wormian bone presence at high prevalance in midline with sagittal or metopic synostosis (Sanchez-Lara et al.). It has been suggested that there was a relationship between wormian bones and osteogenesis imperfecta (Cremin et al.). The shape, number, location and incidence of wormian bones vary as reported in previous studies. A study which focused on the association between artificial deformation and incidence of wormian bones claimed that wormian bones incidence was higher in adults than in fetuses (El-Najjar \& Dawson, 1977).

In a study which analyzed wormian bones in 100 cadaver skulls available at the Department of Anatomy, Andhra Medical College, 10 skulls including wormian bones were observed. They found one wormian bone in four skulls, 2 wormian bones in 2 skulls, 4 wormian bones in 1 skull, 5 wormian bones, and more than five in 2 skulls. They suggested most of them were tetrahedrally-shaped (Vasanthi et al., 2015). In our study, the wormian bone incidence was $42.86 \%(\mathrm{n}=12)$, and most of them were on lambdoid suture $(57.14 \%)$. The wormian bones were seen on lambdoid suture as 20 , on occipitomastoid suture as 3 , on lambda as 3 , on asterion as 6 . A study analyzing wormian bones in terms of gender showed overall incidence of wormian bones as $52.22 \%$, and emphasized that there was one wormian bone on bregma, 25 on lambda, 28 on asterion, 22 on pterion, 5 on parietal notch, 13 on occipitomastoid suture, 1 on coronal suture, 56 on lambdoid suture, 10 on sagittal suture, 5 on squamous suture and 9 on infraorbital region. Moreover, this study also reported the number of wormian bones as follows: 0 (47.8\%), 1 (14,4\%), 2 (9.4\%), 3 (9.4\%), 4 (5\%), 5 (3.9\%), more than five $(9.44 \%)$ (Patil \& Sheelavant). A study in India found that the total incidence of wormian bones was $44.40 \%, 37.03 \%$ on the right side; and $48.10 \%$ on the left side. While most of wormian bones were seen on sutura lamdoidea $(48.14 \%)$; in addition to this, incidents of other wormian bones were distributed according to locations as follows: coronal suture $(0.03 \%)$, occipitomastoid suture $(0.03 \%)$, parietomastoid suture $(0.07 \%)$, asterion $(18.50 \%)$, pterion $(0.03 \%)$, lambda $(0.07$

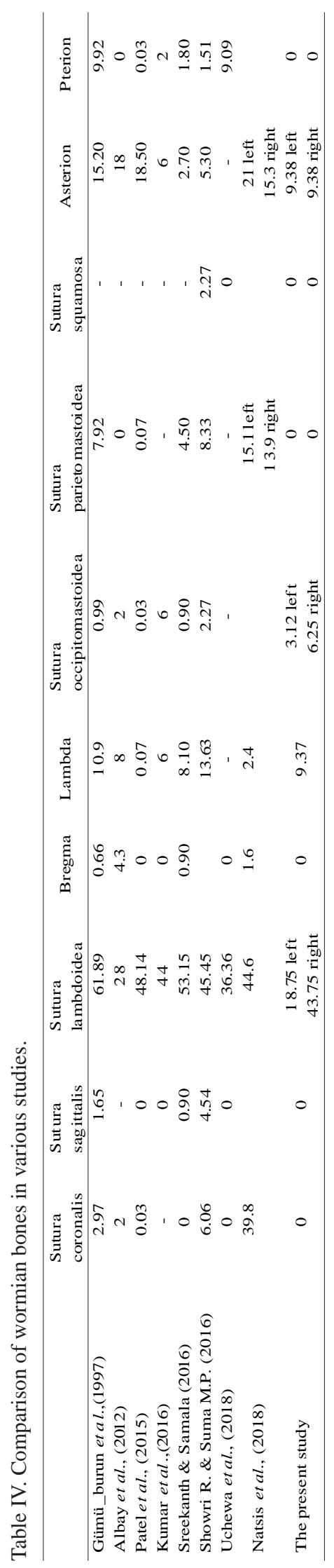


$\%)$. No wormian bones were observed on sagittal suture and bregma. Furthermore, in this study, 1 wormian bone was found in $22 \%$ whereas 2 in $11.10 \%, 3$ in $0.07 \%$, more than 5 in $0.03 \%$ skulls (Patel et al.). A study performed in Telangana, India, reported that wormian bones were observed at lambda $8.10 \%$, pterion $1.80 \%$, asterion $2.7 \%$, parietotemporal suture $4.5 \%$, occipitomastoid suture $0.9 \%$, sagittal suture $0.9 \%$, bregma $0.9 \%$ and the greatest number of wormian bones were observed at lambdoid suture 53.15 $\%$ (Sreekanth \& Samala).

A study analyzing wormian bones according to shapes, locations and incidence, and reported that $52.70 \%$ were quadrangular, $37.83 \%$ were irregular, and $9.45 \%$ were triangular-shaped wormian bones. The most frequent shape was quadrangular in this study as well as in our study. In this study, it was revealed that the most frequent sites of wormian bones was lambdoid suture. It was also indicated that there were $13.63 \%$ at lambda, $8.33 \%$ at parietomastoid suture, $6.06 \%$ at coronal suture, $5.30 \%$ at asterion, $4.54 \%$ at sagittal suture, $2.27 \%$ at occipitomastoid suture, $2.27 \%$ at parietosquamous and $1.51 \%$ at pterion in this study (Showri \& Suma). Himabindu \& Rao reported 1 multiple wormian bone at lambdoid suture, 1 bilateral and 1 rightsided at pterion, 1 at asterion on right and 1 at lambda (os incae) in their study. Additionally, a case report noted multiple wormian bones at lambdoid suture in India (Nayak, 2008). The other case report marked there were 14 wormian bones during their osteology classes, and they claimed that most of their sample had irregular shapes for wormian bones (Tallapaneni et al., 2013). The overall prevalence of wormian bones was $32 \%$; and wormian bones were $36 \%$ on the left side and $22 \%$ on the right side of 50 Indian skulls. Most of the wormian bones were seen at lambdoid suture (44\%), at lambda (6\%), at occipitomastoid suture (6\%), asterion (6 $\%$ ), at pterion (2\%) (Kumat et al., 2016). An investigation performed in Nigerian dried skulls showed the percentage of wormian bones as $45.46 \%$ in total, $36.36 \%$ at lambdoid suture while $9.09 \%$ at pterion. They also emphasized that wormian bones were not seen at coronal suture, bregma and sagittal suture in their study samples (Uchewa et al., 2018). There were some studies focused on wormian bones at asterion.

An investigation in South Indian skulls revealed the presence of wormian bones as $32 \%$ (12\% right, $20 \%$ left) (Ahad \& Thenmozhi, 2015). Likewise, a study conducted in Indian skulls determined wormian bones at asterion as $14.81 \%$ (Singh, 2012). Wormian bone incidence was determined $74.7 \%$ in Greek population, and this study indicated that there were no relationships between wormian bone incidence, sex and age. And the majority of wormian bones were sited at lambdoid suture $(44.6 \%)$, at coronal suture $(39.8 \%)$, at asterion (21\% on left, $13.9 \%$ on right), at parietomastoid suture (15.1\% on left, 13.9 on right). Moreover, wormian bones were not found at occipitomastoid, sagittal sutures, bregma, lambda, pterion (Natsis et al., 2019). When we analyzed these results, it was seen obviously that the majority of wormian bones were seen at lambdoid suture like it was the case in our study.

There were very few studies about wormian bones conducted in our country. A comprehensive study was carried out in 302 Anatolian-Ottoman skulls. Besides examining the presence of wormian bones, this study evaluated wormian bones in terms of skull forms. According to the results of this study, a large amount of wormian bones were seen in brachycephalic group (47\%), just after mesocephalic group $(37.4 \%)$ and dolichocephalic group $(15.6 \%)$ for unilateral wormian bones whereas maximum number of wormian bones were seen at dolicocephalic group in our study (Gümüs burun et al.). Overall incidence of wormian bones were found as $59.3 \%$ among West Anatolian skulls. The maximum and the minimum number of wormian bones were determined at left lambdoid suture $(40.7 \%)$ and at right occipitomastoid suture $(1.3 \%)$. No wormian bones were seen in $40.7 \%$; on the other hand, one wormian bone was seen in $20 \%, 2$ wormian bones were seen in $17.3 \%, 3$ in $8.7 \%, 4$ in $10 \%$, 5 in $2.7 \%$, more than 5 in $0.7 \%$ skulls (Cirpan et al., 2015). A study conducted on 50 skulls with unknown age and sex, it was found that the prevalence of wormian bones was 28 $\%$ at lambdoid suture (highest amount), $2 \%$ at coronal suture, $8 \%$ at lambda, $4.3 \%$ at bregma, $4 \%$ at sutura squamosa, 8 $\%$ at sutura metopica, $18 \%$ at asterion, $2 \%$ at occipitomastoid suture. Vertical and transverse diameters of wormian bones were measured as $17 \pm 6 \mathrm{~mm}$ and $11 \pm 8 \mathrm{~mm}$ for right side and $16 \pm 5 \mathrm{~mm}$ and $9 \pm 6 \mathrm{~mm}$ on left side, respectively; followed by lambdoid suture $17 \pm 6 \mathrm{~mm}, 11 \pm 8$ $\mathrm{mm}$ for right and $16 \pm 5 \mathrm{~mm} 9 \pm 6 \mathrm{~mm}$ for left, at lambda $33 \pm 12$ $\mathrm{mm}$ and $32 \pm 14 \mathrm{~mm}$, at asterion $11 \pm 5 \mathrm{~mm}, 10 \pm 6 \mathrm{~mm}$ for right, $11 \pm 3 \mathrm{~mm}, 7 \pm 3 \mathrm{~mm}$ for left, at occipitomastoid suture $12 \mathrm{~mm}, 7 \mathrm{~mm}(\mathrm{n}=1)$ (Albay et al.). When our results were compared with the literature data, it was determined that wormian bone values and incidence varied between all groups except the most of the wormian bones that were seen at lambdoid suture. These variations may be derived from racial, ethnic and genetic factors (Table IV).

Although there were many variations for rate, location and number of wormian bones, our study results were similar with the literature data in Turkish population with regards to the location of wormian bones as lambdoid suture. Limitations of our study were the small sample size. For that reason, further studies are needed on wormian bones. In conclusion, it is considered that the results of this study are crucial for anthropologists, anatomists, forensic scientists, and make a contribution to literature data. Due to the fact 
that wormian bones may give rise for mistakes in determining fractures, these data also will be helpful for diagnosis and treatment of skull pathologies for clinicians such as neurosurgeons and radiologists.

KILIÇ SAFAK, N.; TASKIN, R. G. \& YÜCEL, A. H. Evaluación morfológica y morfométrica de los huesos wormianos. Int. J. Morphol., 38 (1):69-73, 2020.

RESUMEN: Los huesos wormianos o huesos suturales, son pequeños huesos accesorios ubicados en el cráneo. Estos huesos consisten en centros de osificación adicionales alrededor de las suturas craneales. Este estudio se realizó en 28 cráneos humanos secos con edad y sexo desconocidos en el Departamento de Anatomía de la Universidad de Cukurova. El objetivo del estudio fue investigar la incidencia y determinar las características morfológicas y morfométricas de los huesos wormianos. La incidencia total de presencia de hueso wormiano fue del 42,86\% (n= 12) y la mayoría de estos se localizó en sutura lambdoidea $(57,14$ $\%)$. Los huesos wormianos se observaron en la sutura lambdoidea a una tasa del $62,5 \%$, sutura occipito-mastoidea $9,37 \%$, asterion $18,76 \%$, lambda $9,37 \%$, y no se observaron en suturas pterion, bregma, parietotemporal, sagital y coronal. Los huesos wormianos se observaron en el lado izquierdo a una tasa del 65,62 \% y del $34,38 \%$ en el lado derecho del cráneo. Según nuestro estudio, las formas óseas se consideraron cuadrangulares $(56,26 \%)$, triangulares $(15,62 \%)$ e irregulares $(28,12 \%)$. Los valores medios de los huesos wormianos fueron los siguientes; diámetro vertical: 12,29 \pm 4,48 mm y diámetro horizontal: $10,93 \pm 4,39 \mathrm{~mm}$. Referente al índice cefálico, el resultado de nuestro estudio muestra que la mayoría los cráneos con o sin huesos wormianos pertenecen al grupo dolicocefálico. El conocimiento de las variaciones y características del cráneo es importante para la medicina forense, la anatomía, la radiología y los campos de neurocirugía, como asimismo para los datos de la literatura o las prácticas clínicas.

PALABRAS CLAVE: Huesos wormianos; Ossa suturali; Morfología.

\section{REFERENCES}

Ahad, M. \& Thenmozhi, M. S. Study on asterion and presence of sutural bones in South Indian dry skull. J. Pharm. Sci. Res., 7(6):390-2, 2015.

Albay, S.; Sakallı, B.; Yonguç, G. N.; Kastamoni, Y. \& Edizer, M. Ossa suturalia bulunma sikligi ve morfometrisi. S. D. Ü. Tip. Fak. Derg., 20(1):1-7, 2013.

Anjum, M. I.; Kanwal, S. \& Anjum, M. I. A craniometric study of adult dry skulls in South Punjab. Pak. J. Med. Health Sci., 10(1):244-6, 2016.

Bellary, S. S.; Steinberg, A.; Mirzayan, N.; Shirak, M.; Tubbs, R. S.; CohenGadol, A. A. \& Loukas, M. Wormian bones: a review. Clin. Anat., 26(8):922-7, 2013.

Cirpan, S.; Aksu, F. \& Mas, N. The incidence and topographic distribution of sutures including wormian bones in human skulls. J. Craniofac. Surg., 26(5):1687-90, 2015.

Cremin, B.; Goodman, H.; Spranger, J. \& Beighton, P. Wormian bones in osteogenesis imperfecta and other disorders. Skeletal Radiol., 8(1):358, 1982.
El-Najjar, M. \& Dawson, G. L. The effect of artificial cranial deformation on the incidence of Wormian bones in the lambdoidal suture. Am. J. Phys. Anthropol., 46(1):155-60, 1977.

Gümüs burun, E.; Sevim, A.; Katkici, U.; Adigüzel, E. \& Güleç, E. A study of sutural bones in Anatolian-Ottoman skulls. Int. J. Anthropol., 12(2):43-8, 1997.

Himabindu, A. \& Rao, B. N. An insight into wormian bones. I. J. S. R. E. S., 2:26-8, 2015.

Kumar, T. M. V.; Kumar, V. \& Yadav, N. The occurrence of wormian bones within the cranial sutures and their clinical significance. Int. J. Anat. Res., 4(4):3082-6, 2016.

Natsis, K.; Piagkou, M.; Lazaridis, N.; Anastasopoulos, N.; Nousios, G.; Piagkos, G. \& Loukas, M. Incidence, number and topography of Wormian bones in Greek adult dry skulls. Folia Morphol. (Warsz.), 78(2):359-70, 2019.

Nayak, S. B. Multiple wormian bones at the lambdoid suture in an Indian skull. Neuroanatomy, 7:52-3, 2008.

Patel, D.; Chauhan, K. \& Patil, D. Morphological study of wormian bones in dried human skulls. Nat. J. Med. Res., 5(3):222-5, 2015.

Patil, M. \& Sheelavant, S. Sexual dimorphism among the wormian bones in adult human skulls. J. Indian Acad. Forensic Med., 34(2):124-7, 2012.

Reveron, R. R. Anatomical classification of sutural bones. MOJ Anat Physiol., 3(4):130-1, 2017.

Sanchez-Lara, P. A.; Graham, J. M. Jr.; Hing, A. V.; Lee, J. \& Cunningham, M. The morphogenesis of wormian bones: a study of craniosynostosis and purposeful cranial deformation. Am. J. Med. Genet. A, 143A(24):3243-51, 2007.

Showri, R. \& Suma, M. P. Study of wormian bones in adult human skulls. IOSR J. Dent. Med. Sci., 15(12):54-60, 2016.

Singh, R. Incidence of sutural bones at asterion in adults Indians skulls. Int. J. Morphol., 30(3):1182-6, 2012.

Sreekanth, T. \& Samala, N. Morphological study of wormian bones in dried adult human skulls in Telangana. Int. J. Anat. Res., 4(4):3157-62, 2016.

Tallapaneni, S.; Namrata, C.; Veliginti, S.; Mogili, A.; Zaman, S. \& Hashmi, F. A. Fourteen wormian bones in an adult Indian skull - A rare case report. Med. Sci., 1(3):55-9, 2013.

Uchewa, O. O.; Egwu, O. A.; Egwu, A. J. \& Nwajagu, G. I. Incidence of wormian bones in the dried skull of Nigerian males. Int. J. Anat. Var., 11(1):32-4, 2018.

Yücel, A.H. Dere Anatomi Atlası ve Ders Kitabı. $7^{\text {th }}$ ed. Ankara, Akademisyen Yayınevi, 2018.

\section{Corresponding author:}

Nazire KILIÇ SAFAK

Cukurova University

Faculty of Medicine

Department of Anatomy

01330 Adana

TURKEY

Email: nazirekilic84@gmail.com

Received: 19-04-2019

Accepted: 05-08-2019 